\title{
PRACOWNIK, ARTYSTA CZY PREKARIUSZ - W POSZUKIWANIU PROTOPLASTY E-SPORTOWCA NA KANWIE PRAWA PRACY
}

\begin{abstract}
Abstrakt: W ostatnich dekadach e-sport zyskuje na znaczeniu. Jest to ważny sektor współczesnej gospodarki, w którym pracę znajdują tysiące osób. W obecnym stanie prawnym brak jest umowy dedykowanej potrzebom współczesnego e-sportu w zakresie zatrudnienia. E-sportowcy mogą zatem korzystać zarówno z umowy o pracę, umowy cywilnoprawnej, jak i umowy zawieranej w ramach własnej działalności gospodarczej. Niniejszy artykuł ma na celu zbadanie charakteru zatrudnienia w sporcie, a w szczególności ma podjąć próbę wskazania protoplasty e-sportowca na kanwie prawa pracy.
\end{abstract}

Słowa kluczowe: e-sport, prawo pracy, umowa o pracę, protoplasta, prawo sportowe

\section{WPROWADZENIE}

Jak słusznie przewidział ponad wiek temu Nikola Tesla, ,wkrótce będzie możliwe bezprzewodowe wysyłanie informacji na cały świat, każdy człowiek będzie mógł to robić przy pomocy małego urządzenia noszonego przy sobie [...]. Niedrogie urządzenie, nie większe niż zegarek, będzie w stanie transmitować dźwięk przez morza i lądy na dystansie setek mil"'. Jego przyszłość jest naszą teraźniejszością. Praktycznie każdy aspekt naszego życia uległ na przestrzeni ostatnich lat cyfryzacji, zwłaszcza proces świadczenia usług czy wykonywania przez nas pracy. Wiele zawodów, które jeszcze kilkadziesiąt lat temu towarzyszyły ludzkości na drodze jej rozwoju, obecnie są praktycznie niewykonywane, a ich znaczenie $\mathrm{w}$ gospodarce jest marginalne. $\mathrm{Z}$ drugiej zaś strony wykreowano zupełnie nowe profesje, bez których nie możemy sobie wyobrazić współczesnej codzienności.

Jeszcze parę lat temu wielu obserwatorów życia codziennego, w tym również wybitnych badaczy, powątpiewało w znaczenie społeczne oraz gospodarcze sportu

${ }^{1}$ How Nikola Tesla Predicted the Blackberry, https://www.foxnews.com/tech/how-nikola-tesla-predicted-the-blackberry (dostęp: 1.05.2020). 
elektronicznego, traktując je tym samym jako przejściowy kaprys niezrozumiałego młodego pokolenia. Ostatnie lata pokazały jednakże że zarówno w ujęciu ilościowym, jak i jakościowym e-sport stał się częścią współczesnej rzeczywistości i angażuje coraz więcej osób, pozyskując przy tym niewyobrażalne środki finansowe. Pomimo ostrożności, z jaką należy podchodzić do wszelkich twierdzeń na temat przyszłości człowieka, można pokusić się o prognozę, że w dobie tak szybko postępującej cyfryzacji tylko jakiś niewyobrażalny huragan zdarzeń byłby zdolny zatrzymać wykładniczy rozwój e-sportu na świecie; rozwój, który początkowo naturalnie skupiał się w najbardziej rozwiniętych rejonach globu, aby następnie upowszechnić się pod wszystkimi szerokościami geograficznymi.

\section{CHARAKTERYSTYKA SPORTU ELEKTRONICZNEGO}

Sport elektroniczny, inaczej zwany e-sportem ${ }^{2}$, jest to - nieco upraszczając samą definicję - spędzanie czasu na grze w gry komputerowe rozumiane jako programy umożliwiające użytkownikowi pewne manipulacje, które generują widoczne zmiany na ekranie, w celu rywalizacji z innymi graczami i finalnego wygrania z nimi w danej grze ${ }^{3}$. Sport elektroniczny, podobnie jak sport tradycyjny, można podzielić na: gaming (odpowiednik rekreacyjnego uprawienia sportu) oraz pro-gaming (odpowiednik zawodowego uprawiania sportu). Prawdą jest, że w obecnych realiach coraz popularniejsze staje się uprawianie sportu elektronicznego w sposób wyczynowy, nakierowany na pozyskiwanie dzięki niemu środków niezbędnych do bieżącego utrzymania. Dla wielu osób środki uzyskiwane z e-sportu są jedynym źródłem dochodu.

W szeroko rozumianej doktrynie sportu rozgorzały liczne spory o to, czy e-sport winien być zaliczony do sportu ze wszystkimi tego konsekwencjami. Pojawia się coraz więcej opracowań wskazujących na posiadanie przez sporty elektroniczne konstytutywnych cech sportu w rozumieniu tradycyjnym, do których zaliczyć można: (1) odrębność motywów ich uprawiania od podstawowych potrzeb życiowych, (2) pozytywne emocje towarzyszące tym działaniom, (3) brak materialnego efektu, (4) istnienie ruchowego charakteru, (5) systematyczne dążenie do maksymalizacji osiąganych wyników, (6) kluczowe znaczenie współzawodnictwa jako bodźca do samodoskonalenia, (7) stosowanie się do ścisłych wytycznych w sprawach technicznych i regulaminowych ${ }^{4}$. Wydaje się, że przy uwzględnieniu odrębnej specyfiki e-sportu możliwe jest zakwalifikowanie go jako sportu w szerokim tego rozumieniu. W przyszłości, w razie osiągnięcia symbiozy pomiędzy

2 Oba terminy są w istocie rzeczy tożsame. Pojęcie e-sportu to akronim formuły electronic sport, a więc de facto również polskiego elektronicznego sportu.

3 A. Stępnik, E-sport z perspektywy teorii sportu, „Homo Ludens” 2009, nr 1, s. 214-215.

4 Ibidem, s. 216-217. 
sportem tradycyjnym a sportem elektronicznym, możliwe byłoby uzyskanie korzyści dla obu tych dziedzin. Sport wielokrotnie ewoluował i podlegał licznym przeobrażeniom na przestrzeni wieków, również współcześnie nie jest odporny na zewnętrzne wobec niego procesy, zwłaszcza te ściśle związane z jego komercyjnym potencjałem.

Lista gier, w których odbywają się rozgrywki e-sportowe jest znaczna mogą one być odpowiednikiem dyscyplin w sporcie rozumianym tradycyjnie. Należą do nich między innymi Overwatch, Quake, Counter-Strike, Call of Duty, League of Legends, Dota 2, Smite, Grand Turismo Sport, StarCraft, Warcraft III, FIFA Football, Madden NFL, Gears of War, Fortnite. Rozgrywki toczą się w licznych gatunkach gier: RPG, akcji, sportowych oraz przygodowych. Społeczność sportu elektronicznego jest znaczna i z każdym rokiem coraz większa. W 2019 roku rozgrywki śledziło, przede wszystkim za pomocą internetu, ponad 450 milionów osób, w tym prawie trzy miliony w Polsce, generując wpływy z biletów przekraczające pięćdziesiąt milionów złotych oraz wyznaczając wartość tego rynku na ponad miliard dolarów ${ }^{5}$.

Zarobki osiągane w sportach elektronicznych przez graczy na świecie, ale również w Polsce, stają się nieosiągalne dla zdecydowanej większości osób zajmujących się innymi profesjami. W ostatnich latach wynagrodzenia zaczynają się zbliżać do zarobków osiąganych przez sportowców w dyscyplinach tradycyjnych. Według danych na rok 2019 najwięcej w całej swojej karierze wśród Polaków zarobili: Filip „NEO” Kubski (około 730 tysięcy USD), Wiktor „Taz” Wojtas (około 715 tysięcy USD), Jarosław ,pashaBiceps” Jarząbkowski (około 625 tysięcy USD) czy Janusz „Snax” Pogorzelski (około 610 tysięcy USD) ${ }^{6}$. Zagraniczne gwiazdy e-sportu, między innymi Niemiec Kuro „KuroKy” Takhasomi czy Jordańczyk ${ }^{7}$ Amer „Miracle” Al-Barkawi, zarobiły w swojej karierze już ponad cztery miliony dolarów.

E-sportowcy trenują zazwyczaj przez kilkadziesiąt godzin tygodniowo, aby móc rywalizować na najwyższym poziomie z innymi graczami w najbardziej prestiżowych rozgrywkach. Zgodnie z dostępnymi informacjami gracze trenują drużynowo od ośmiu do nawet trzynastu godzin dziennie ${ }^{8}$. Sporty elektroniczne, podobnie jak inne działalności człowieka, wymagają poświęcenia im tysięcy godzin, aby osiągnąć poziom mistrzowski. Niektórzy naukowcy określają ten próg

5 E-sport w Polsce coraz popularniejszy. Śledzi go ponad 3 mln osób, https://gamingsociety. $\mathrm{pl} /$ artykul/esport-w-polsce-popularnosc-758660/ (dostęp: 1.05.2020).

${ }^{6}$ Infografika: Najlepiej zarabiajacy polscy esportowcy. Jak wypadaja na tle graczy z zagranicy i sportowców?, https://esportmania.pl/biznes/zarobki-w-esporcie-oto-najlepiej-zarabiajacyesportowcy-infografika/12kysxf (dostęp: 1.05.2020).

7 Matka tego gracza jest Polką, a on sam posiada dwa obywatelstwa, w tym polskie.

${ }^{8}$ M. Ogonowski, Esport w pigutce. Ile kto zarabia?, https://sport.tvp.pl/42072397/zarobki-wesporcie-ile-zarabia-gracz-ile-zarabia-komentator-ile-zarabia-administrator-ile-zarabia-zawodnikesport-zarabianie-kasa-pieniadze-jak-dziala-organizacja (dostęp: 1.05.2020). 
w przybliżeniu na dziesięć tysięcy godzin ${ }^{9}$, co przy użyciu prostego działania matematycznego daje ponad czterysta dni. Pociąga to za sobą liczne konsekwencje zarówno w sferze zawodowej, jak i prywatnej zawodnika, który nie dysponuje tym samym czasem wolnym na podjęcie innego zatrudnienia. Profesjonalne uprawianie sportów elektronicznych wymusza w znacznym stopniu ograniczenie innych aktywności zawodowych oraz naukowych i dostosowanie swojego kalendarza do terminów poszczególnych treningów oraz rozgrywek. W swojej istocie wykonywanie pracy e-sportowej $\mathrm{w}$ wielu aspektach jest tożsame $\mathrm{z}$ wykonywaniem pracy sportowej.

\section{E-SPORTOWIEC W ZATRUDNIENIU}

Katalog podstaw, na jakich dochodzi do zatrudniania e-sportowców, jest tożsamy z właściwym dla sportowców, a należy do niego: umowa o pracę, umowa cywilnoprawna lub umowa zawierana w ramach prowadzonej własnej działalności gospodarczej. W polskim systemie prawnym nie istnieje żaden akt prawny, który modyfikowałby ten katalog i wprowadzał szczególny rodzaj umowy dedykowanej potrzebom sportu oraz e-sportu ${ }^{10}$. Zarówno w przypadku e-sportu, jak i sportu tradycyjnego wybór reżimu prawa pracy przez strony jest nieznaczny ${ }^{11}$. Jest to spowodowane szeregiem pierwotnych przyczyn, między innymi wyższymi kosztami takiego zatrudnienia, wysoką zmiennością zatrudnienia w e-sporcie oraz niedostosowaniem licznych przepisów zawartych w kodeksie pracy do sytuacji faktycznej e-sportowca. Skutkiem takiego stanu rzeczy jest nieobjęcie samego zawodnika ochroną przewidzianą w kodeksie pracy, w tym w ramach zbiorowego prawa pracy.

Należy jednak podkreślić, że o charakterze danej umowy nie decyduje jej nazwa, lecz treść, co implikuje liczne konsekwencje, w tym możliwość ustalenia wbrew nazwie - że mamy do czynienia z umową o pracę, o której mowa w art. 22 kodeksu pracy. Strony mają na podstawie art. $353^{1}$ kodeksu cywilnego możliwość ułożenia stosunku prawnego według własnego uznania, byleby jego treść lub cel nie sprzeciwiały się właściwości stosunku, ustawie ani zasadom współżycia spo-

${ }^{9}$ M. Herman, Znamy wyniki wielkiego badania polskiego e-sportu!, https://www.redbull. $\mathrm{com} / \mathrm{pl}$-pl/wielkie-badanie-esportu-w-polsce-raport-kantar-millward-brown (dostęp: 1.05.2020).

10 Analiza racjonalności i konieczności wprowadzenia takiego rodzaju umowy do polskiego systemu prawnego została szczegółowo przedstawiona w pracy doktorskiej Umowa o prace sportowa przygotowanej w 2020 roku w Katedrze Prawa Pracy na Wydziale Prawa i Administracji Uniwersytetu Łódzkiego. W dysertacji szczegółowo przedstawiono możliwości wykorzystania umów o pracę oraz cywilnoprawnej w sporcie.

11 M. Passon, M. Różyczka, Wybrane problemy zwiazane ze statusem zawodnika e-sportowego w świetle zbiorowego prawa pracy w Polsce, „Internetowy Przegląd Prawniczy Towarzystwa Biblioteki Słuchaczów Prawa Uniwersytetu Jagiellońskiego” 2018, nr 3, s. 87-88. 
łecznego. Kontrakty zawierane w sporcie elektronicznym są w praktyce silnie zróżnicowane wewnętrznie i trudno mówić o jednym schemacie takiej umowy. Do kluczowych prawnych aspektów, które winny być uregulowane, należą: odpłatność stosunku prawnego oraz zasady wypłaty wynagrodzenia, długość trwania kontraktu, możliwość jego przedwczesnego rozwiązania oraz prawa i obowiązki stron. Zróżnicowanie umów e-sportowców, które zawierane są głównie w reżimie prawa cywilnego, wynika z każdorazowej pozycji negocjacyjnej danego zawodnika oraz jego pełnomocników, w tym ich zdolności do ustalenia korzystnych postanowień prawnych.

Sportowcy elektroniczni stosunkowo często działają w ramach samozatrudnienia $^{12}$, udostępniając swoje usługi (w razie zaistnienia takiej konieczności) chętnym klubom, drużynom oraz innym podmiotom. Część sportowców elektronicznych występuje w rozgrywkach indywidualnie. Istotną część dochodów sportowców stanowią ponadto środki uzyskane w ramach zdobytych nagród w poszczególnych turniejach, środki uzyskane od sponsorów oraz dotacje (napiwki) uzyskiwane od fanów, którzy chcą na bieżąco wspierać swoich idoli.

Na co dzień spotkać można jeszcze lekceważące opinie na temat e-sportowców, które wskazują jakoby: (1) pracę e-sportową mógł wykonywać każdy, (2) granie na komputerach było infantylne, (3) gracze mogli oddawać się bardziej pożytecznym aktywnościom, (4) grający mogli prowadzić tryb życia zdrowszy od ciągłego siedzenia przy komputerze, (5) granie w gry komputerowe nie może być zakwalifikowane jako zawód ${ }^{13}$. Niewątpliwie każde nowe zjawisko budzi liczne kontrowersje, a negatywne opinie często wynikają z braku posiadania szerszej wiedzy na jego temat.

Do węzłowych problemów w zatrudnieniu we współczesnym sporcie tradycyjnym oraz sporcie elektronicznym należy zaliczyć postępujące procesy uberyzacji oraz prekaryzacji zatrudnienia. Te dwa procesy, chociaż występują również w innych sektorach gospodarki, to jak w soczewce skupiają problemy sportu, zwłaszcza elektronicznego.

\section{W POSZUKIWANIU PROTOPLASTY E-SPORTOWCÓW}

Prekaryzacja może być rozumiana wielorako, w tym jako: (1) proces stanowiący kolejny krok w rozwoju kapitalistycznych stosunków produkcji, regres wobec

12 Więcej o tej problematyce w dalszej części niniejszego opracowania dotyczącej uberyzacji pracy w sporcie elektronicznym.

13 Informacje uzyskane w bardzo podstawowych badaniach osób z mojego najbliższego otoczenia. Przytoczone w tekście spostrzeżenia są najczęściej uzyskiwanymi odpowiedziami na moje pytanie o istotę i sens funkcjonowania e-sportu. W zdecydowanej większości respondenci przejawiali stosunek ambiwalentny, niekiedy nawet negatywny. Jednocześnie te osoby same wskazywały, że nie posiadają dużej wiedzy na temat sportu elektronicznego jako współczesnego zjawiska. 
uprzednich socjalnych osiągnięć klasy robotniczej ${ }^{14}$, (2) pewien stan niepewności, który nie mieści się w ramach tradycyjnego podziału społecznego statusu ${ }^{15}$, (3) zjawisko wynikające z samej etymologii słowa prekariat składającego się ze słów: niepewny oraz proletariat ${ }^{16}$. Ogólnie rzecz ujmując, prekariusze to kategoria ludzi, która doświadcza deficytów bezpieczeństwa związanych z zatrudnieniem, między innymi w zakresie braku stałej pracy, braku awansu społecznego, braku tożsamości zawodowej, które prowadzić mogą do negatywnych konsekwencji w sferze psychicznej ${ }^{17}$. Ryzyko prekaryzacji nie dotyczy jedynie osób o niskim statusie społecznym, ale również innych grup, w tym między innymi lekarzy rezydentów czy aplikantów radcowskich.

$\mathrm{Z}$ drugiej strony istnieje pojęcie uberyzacji, które może być rozumiane jako istotny element ekonomii współdzielenia polegającej na otrzymywaniu pewnych dochodów w zamian za dzielenie się posiadanymi dobrami: czasem wolnym, twórczością czy środkami pieniężnymi ${ }^{18}$. Polega ona na dostarczaniu usług na żądanie w formie mikroaktywności gospodarczej, która polega na dostarczaniu produktów lub usług dokładnie w momencie zgłoszenia zapotrzebowania ${ }^{19}$. W przypadku zatrudnienia ta nowa forma polega na wymianie dóbr przez użytkowników pewnych sieci, które pozwalają swoim użytkownikom na dostęp do innych użytkowników w celu osiągnięcia określonych zamiarów ${ }^{20}$. Początkowo rozwój zjawiska współdzielenia odbywał się za pomocą platform gigantów technologicznych takich, jak: Amazon Mechanical Turk, Crowdflower, Lyft, Deliveroo czy wreszcie Uber, od którego nazwy powstał badany neologizm: uberyzacja ${ }^{21}$. Skutkami uberyzacji zatrudnienia, poza jego uelastycznieniem, są: (1) jego dorywczość i fragmentaryzacja, (2) niski poziom praw zbiorowych, (3) brak stałości zatrudnienia oraz (4) brak tradycyjnej więzi między pracodawcą a pracownikiem ${ }^{22}$.

Oba zjawiska nie są od siebie zupełnie odrębne, bowiem uberyzacja zatrudnienia zazwyczaj prowadzi do jego prekaryzacji, zjawiska niekiedy nawet do tak

14 Ł. Rąb, Prekariat i prekaryzacja pracy w epoce globalizacji, „Zeszyty Naukowe. Organizacja i Zarządzanie” 2016, z. 92, s. 270-271.

15 K. Kocemba, Prekaryzacja młodych prawników w Polsce, „Folia Iuridica Universitatis Wratislaviensis" 2018, nr 7, s. 248-249.

16 Ibidem.

17 P. Czakon, Prekaryzacja pracy. Propozycja socjologicznego ujęcia zjawiska, „Zeszyty Naukowe. Organizacja i Zarządzanie" 2017, z. 112, s. 124-125.

18 T. Bakalarz, Zatrudnienie za pośrednictwem platformy internetowej jako przejaw , uberyzacji” pracy, „Przegląd Prawa i Administracji” 2019, nr 117, s. 9.

19 Ibidem.

20 Ibidem, s. 11-12.

21 B. Bednarowicz, „Uberyzacja zatrudnienia” - praca $w$ gospodarce współdziałania w świetle prawa UE, „Monitor Prawa Pracy” 2018, nr 2, s. 13-16.

22 Ibidem. 
zwanego cyberiatatu, rozumianego jako wykonywanie pracy przez cyfrowych niewolników w cyfrowych zakładach pracy ${ }^{23}$.

Istota wykonywania pracy sportowej w formie elektronicznej sama w sobie niesie zagrożenie wykluczeniem w zatrudnieniu. Zatrudnienie w sektorze e-sportu związane jest z niezwykle częstą zmianą klubów sportowych, które mogą być w tradycyjnym zatrudnieniu rozumiane jako pracodawcy, krótkotrwałością zatrudnienia, brakiem tradycyjnego podporządkowania oraz więzi pomiędzy osobą zatrudniającą a wykonującą pracę. W praktyce świadczenie usług przez sportowców elektronicznych odbywa się powszechnie na zasadzie zbliżonej do działania platformy Uber - do każdorazowych potrzeb danego zespołu poszukiwany jest konkretny zawodnik, który otrzymuje wynagrodzenie za reprezentowanie jego barw. Kiedy turniej się kończy, zawodnik dostępny jest na platformie, która może być rozumiana jako ograniczona społeczność e-sportowców, dla innych drużyn do przyszłych turniejów. Jeżeli takiego zapotrzebowania w przyszłości nie będzie sportowiec nie osiąga wynagrodzenia, są oni zatem elastycznym usługodawcą (just-in-time workforce) wynagradzanym w systemie repartycyjnym (pay-as-you$-g o)^{24}$.

Należy jednoznacznie wskazać, że wyżej opisane zjawisko - chociaż powszechne - nie jest jedynym rozwiązaniem problemu zatrudnienia w sporcie elektronicznym. Tak jak przedstawiono to we wcześniejszej części niniejszego opracowania, niektórzy e-sportowcy korzystają z umów cywilnoprawnych lub (sporadycznie) umów o pracę. W ogólnym ujęciu jedynie nieznacznie zmniejsza to realność zagrożenia zjawiskiem prekariatu w tej grupie społecznej.

Jak przed laty pisał Władysław Stanisław Reymont, ,,artyzm to szalona ruchliwość wrażliwości mózgowej i czuciowej, co wszystko wchłania i rozlewa się na wszystko, i dąży przede wszystkim do tego, żeby swoje ja zatracić" ${ }^{25}$. Niezmiernie ciekawą dyskusją jest zawsze temat występowania artyzmu u sportowców czy, obecnie, u e-sportowców. Dla fanów sportu oczywistością jest rozróżnienie zawodników-rzemieślników od zawodników-artystów, do których możemy zaliczyć między innymi Andresa Iniestę ${ }^{26}$, Lionela Messiego czy Rogera Federera. Jak mawiał Seth Godin, ,artyści są ludźmi z talentem do znajdywania nowych odpowiedzi, nowych połączeń oraz nowych sposobów do wykonywania danych rzeczy"27. Codziennie zmuszeni są oni do poszukiwania nowych ścieżek rozwoju, adaptacji do zmieniającego się otoczenia, dopracowywania najmniejszych detali

23 Ibidem, s. 13.

24 Ibidem.

25 W.S. Reymont, Komediantka, http://wspolnotapolska.org.pl/kultura/literatura/reymont/ komediantka.pdf, s. 66 (dostęp: 14.05.2020).

${ }^{26}$ W 2016 roku wydawnictwo Sine Qua Non opublikowało w Polsce książkę Andres Iniesta. Artysta futbolu. Gra mojego życia.

27 T. Reklaitis, Why All Athletes are Artists. Change the Way You Think about Your Time as an Athlete, https://tanners.blog/2019/01/22/athletes-are-artists/ (dostęp: maj 2020), tłumaczenie własne. 
własnego warsztatu. Ich występy są na bieżąco śledzone nawet przez miliony widzów, z których część w zaciszu własnego domu lub na lokalnych obiektach sportowych próbuje naśladować zagrania wielkich mistrzów.

W konsekwencji o tym, czy dany e-sportowiec będzie przez swoich kibiców i sympatyków postrzegany jako artysta, decydować będą łącznie następujące czynniki: (1) naturalny talent, (2) unikatowe cechy osobowościowe, (3) podejście do życia oraz do wykonywanych obowiązków, (4) wytrwała praca treningowa. E-sportowcy-rzemieślnicy to najczęściej osoby, które bazują tylko na punkcie czwartym, a więc jedynie dzięki bardzo ciężkiej pracy są w stanie osiągać względne sukcesy w sporcie elektronicznym.

$\mathrm{Na}$ gruncie zatrudnienia występują liczne podobieństwa w sytuacji prawnej oraz faktycznej pomiędzy e-sportowcami a artystami. Obie grupy zawierają swoiste kontrakty, które mogą przybierać charakter umów prawa cywilnego, umowy o pracę lub samozatrudnienia. W stosunku do obu kategorii osób praco- lub zleceniodawcy mają inne oczekiwania niż wobec pracowników administracyjnych, takie, które nie opierają się w tak znacznym stopniu na podporządkowaniu występującym najczęściej w sferze pracy organizacyjnej ${ }^{28}$.

\section{PODSUMOWANIE}

Poszukiwania protoplasty e-sportowca na kanwie prawa pracy nie należą do zagadnień o naturze homogenicznej. Pomimo tego że wykonywanie pracy e-sportowej jest zjawiskiem wciąż nowym, to czerpie ze zjawisk pokrewnych, które towarzyszyły ludzkości w ostatnich dekadach. Przedstawiona charakterystyka sportowca elektronicznego prowadzi do konkluzji analogicznych do specyfiki wykonywania pracy sportowej w jej klasycznym rozumieniu. E-sportowcy w wykonywaniu swojej pracy jedynie w wąskim zakresie czerpią z doświadczeń pracowniczych. Współcześnie są oni dotknięci zewnętrznymi procesami uberyzacji oraz prekaryzacji, które charakteryzują się brakiem stałości i dużą rotacją w zatrudnieniu, prowadząc tym samym do wielu zagrożeń.

Czy zatem sportowiec elektroniczny może być pracownikiem? Na tak postawione pytanie należy odpowiedzieć jednoznacznie, że ramy kodeksu pracy są na tyle szerokie, iż wykonywanie pracy e-sportowej bezsprzecznie zmieściłoby się w nich po zastosowaniu procesów dyferencjacji. Współcześnie jednak umowy o pracę praktycznie nie stosuje się w sportach elektronicznych, dlatego też trudno szukać zarówno protoplasty, jak i współczesnego odpowiednika w tym obszarze.

Podstawy prawne zatrudnienia artystów oraz sportowców są zbieżne, a sama ich charakterystyka jest w wielu aspektach niemalże tożsama. Pojęcie artysty nie

28 Zob. M. Gładoch, Specyfika zatrudnienia artystów na podstawie umowy o pracę, [w:] „Praca i Zabezpieczenie Społeczne” 2018, nr 11. 
doczekało się definicji legalnej, ani też żadnej innej, która w sposób powszechny oraz kompleksowy ujmowałaby artystów w ramy pojęcia prawnego. Do katalogu współczesnych artystów możemy zaliczyć przedstawicieli wielu zawodów, w tym w pewnym zakresie również sportowców oraz e-sportowców, którzy - niczym malarze lub pianiści - dopracowują przez lata detale swojego warsztatu, by osiągnąć nieuchwytny ze swojej natury artyzm. Wracając do początków sportu w codziennym życiu człowieka, należy wskazać, że jedną z jego głównych funkcji miało być niesienie rozrywki obywatelom — podobnie jak w wypadku aktorstwa, muzyki czy sztuk plastycznych. Wraz z rozwojem nowoczesnych technologii podobne zadania wykonywane są obecnie również przez e-sportowców.

Zatrudnienie w sektorze sportu elektronicznego niesie ze sobą zagrożenia prekaryzacją i uberyzacją na zasadach opisanych w niniejszej pracy. Dostęp w sektorze e-sportu do zabezpieczenia pracowniczego i społecznego jest niewielki, co wynika częściowo z samej natury tej gałęzi gospodarki, częściowo zaś z woli samych stron.

Gdzie zatem szukać należy protoplasty e-sportowców na kanwie prawa pracy? Po części w każdym z tych pojęć: pracowniku, artyście oraz prekariuszu, a po części w każdym z nas. Sport, w tym sport elektroniczny, nie jest zewnętrzny wobec ludzkości, stanowi raczej część szeroko rozumianego człowieczeństwa. Obecne zatrudnienie w sporcie elektronicznym cechuje się dużym zróżnicowaniem wewnętrznym, znaczną rotacją, minimalną stałością zatrudnienia i brakiem głębszych więzi pomiędzy zawodnikami, a ich drużyną czy klubem. Część z e-sportowców osiąga bardzo wysokie dochody, a inni nie odzyskują nawet bieżących kosztów profesjonalnego sprzętu. Z tych względów sportowi elektronicznemu w sferze zatrudnienia zdecydowanie bliżej do prekariatu niż do tradycyjnie rozumianego stosunku pracy.

\section{EMPLOYEE, ARTIST OR PRECARIOUS — IN SEARCH OF AN ANCESTOR OF AN E-SPORT PLAYER ON THE BASIS OF LABOR LAW}

\section{Summary}

Nowadays, e-sport is gaining importance. It is an important sector of the modern economy in which thousands of people find employment. In the current legal system, there is no contract dedicated to the needs of modern e-sport in terms of employment. E-sportsmen can use: an employment contract, a civil law contract, and a contract concluded as part of their own business. The goals of this article are: to examine the nature of employment in sport and in particular, to try to find the ancestor of an e-athlete based on labor law.

Keywords: e-sport, labor law, employment contract, ancestor, sports law 


\section{BIBLIOGRAFIA}

Bakalarz T., Zatrudnienie za pośrednictwem platformy internetowej jako przejaw „uberyzacji” pracy, „Przegląd Prawa i Administracji” 117, 2019.

Bednarowicz B., ,Uberyzacja zatrudnienia” - praca w gospodarce współdziałania $w$ świetle prawa UE, ,Monitor Prawa Pracy” 2018, nr 2.

Czakon P., Prekaryzacja pracy. Propozycja socjologicznego ujęcia zjawiska, „Zeszyty Naukowe. Organizacja i Zarządzanie” 2017, z. 112.

E-sport w Polsce coraz popularniejszy. Śledzi go ponad 3 mln osób, https://gamingsociety.pl/artykul/ esport-w-polsce-popularnosc-758660/.

Gładoch M., Specyfika zatrudnienia artystów na podstawie umowy o pracę, „Praca i Zabezpieczenie Społeczne”,, 2018, nr 11.

Herman M., Znamy wyniki wielkiego badania polskiego e-sportu!, https://www.redbull.com/pl-pl/ wielkie-badanie-esportu-w-polsce-raport-kantar-millward-brown (dostęp: 1.05.2020).

How Nikola Tesla Predicted the Blackberry, https://www.foxnews.com/tech/how-nikola-teslapredicted-the-blackberry (dostęp: 1.05.2020).

Infografika: Najlepiej zarabiajacy polscy esportowcy. Jak wypadaja na tle graczy z zagranicy i sportowców?, https://esportmania.pl/biznes/zarobki-w-esporcie-oto-najlepiej-zarabiajacyesportowcy-infografika/12kysxf.

Kocemba K., Prekaryzacja młodych prawników w Polsce, „Folia Iuridica Universitatis Wratislaviensis" 2018, $\mathrm{nr} 7$.

Ogonowski M., Esport w pigutce. Ile kto zarabia?, https://sport.tvp.pl/42072397/zarobki-w-esporcie-ile-zarabia-gracz-ile-zarabia-komentator-ile-zarabia-administrator-ile-zarabia-zawodnikesport-zarabianie-kasa-pieniadze-jak-dziala-organizacja (dostęp: 1.05.2020).

Passon M., Różyczka M., Wybrane problemy zwiazane ze statusem zawodnika e-sportowego wświetle zbiorowego prawa pracy w Polsce, „Internetowy Przegląd Prawniczy Towarzystwa Biblioteki Słuchaczów Prawa Uniwersytetu Jagiellońskiego" 2018, nr 3.

Rąb Ł., Prekariat i prekaryzacja pracy w epoce globalizacji, „Zeszyty Naukowe. Organizacja i Zarządzanie" 2016, z. 92.

Reklaitis T., Why All Athletes are Artists. Change the Way You Think about Your Time as an Athlete, https://tanners.blog/2019/01/22/athletes-are-artists/ (dostęp: 1.05.2020).

Reymont W.S., Komediantka, http://wspolnotapolska.org.pl/kultura/literatura/reymont/komediantka.pdf, s. 66 (dostęp: 14.05.2020).

Stępnik A., E-sport z perspektywy teorii sportu, „Homo Ludens” 2009, nr 1. 